\title{
Microvascular oxygen extraction during maximal isometric contraction in patients with chronic obstructive pulmonary disease
}

\author{
Extração microvascular de oxigênio durante contração \\ isométrica máxima em pacientes com DPOC não hipoxêmicos
}

\author{
Flavia Fernandes Manfredi de Freitas ${ }^{[a]}$, Diego Paiva de Azevedo ${ }^{[a]}$, Wladimir Musetti Medeiros ${ }^{[\mathrm{b}]}$, \\ José Alberto Neder $^{[b]}$, Luciana Dias Chiavegato ${ }^{[a, b]}$, Cesar Ferreira Amorim ${ }^{[a]^{*}}$ \\ [a] Universidade Cidade de São Paulo (UNICID), São Paulo, SP, Brazil \\ [b] Universidade Federal de São Paulo (UNIFESP), São Paulo, SP, Brazil
}

\begin{abstract}
Introduction: COPD presents decrease in oxidative metabolism with possible losses of cardiovascular adjustments, suggesting slow kinetics microvascular oxygen during intense exercise. Objective: To test the hypothesis that chronic obstructive pulmonary disease (COPD) patients have lower muscle performance in physical exercise not dependent on central factors, but also greater muscle oxygen extraction, regardless of muscle mass. Methods: Cross-sectional study with 11 COPD patients and nine healthy subjects, male, paired for age. Spirometry and body composition by DEXA were evaluated. Muscular performance was assessed by maximal voluntary isometric contraction (MVIC) in isokinetic dynamometer and muscle oxygen extraction by the NIRS technique. Student t-test and Pearson correlation were applied. A significance level of p $<0.05$ was adopted. Results: Patients had moderate to severe COPD (FEV1 $=44.5 \pm 9.6 \%$ predicted; SpO2 $=94.6 \pm 1.6 \%$ ). Lean leg mass was $8.3 \pm 0.9$ vs. $8.9 \pm 1.0 \mathrm{~kg}(\mathrm{p}=0.033)$, when comparing COPD and control patients, respectively. The decreased muscle oxygen saturation corrected by muscle mass was $53.2 \%$ higher
\end{abstract}

*FFMF: MS, e-mail: ffmanfred@yahoo.com.br DPA: MS, e-mail: d_pazevedo@yahoo.com.br WMM: PhD, e-mail: wmusettimedeiros@hotmail.com JAN: PhD, e-mail: nederalb@gmail.com LDC: PhD, e-mail: lu_chiavegato@uol.com.br CFA: PhD, e-mail: cesar@emgsystem.com.br 
$(\mathrm{p}=0.044)$ in the COPD group in MVIC-1 and $149.6 \%$ higher $(\mathrm{p}=0.006)$ in the MVIC-2. Microvascular extraction rate of oxygen corrected by muscle mass and total work was found to be $114.5 \%$ higher ( $\mathrm{p}=0.043$ ) in the COPD group in MVIC-1 and $210.5 \%$ higher $(\mathrm{p}=0.015)$ in the MVIC-2. Conclusion: COPD patients have low muscle performance and high oxygen extraction per muscle mass unit and per unit of work. The high oxygen extraction suggests that quantitative and qualitative mechanisms can be determinants of muscle performance in patients with COPD.

Keywords: Chronic Obstructive Pulmonary Disease. Isometric Contraction. Muscle Strength. Oxygen Consumption. Metabolism.

\section{Resumo}

Introdução: DPOC (doença pulmonar obstrutiva crônica) apresenta diminuição no metabolismo oxidativo com prejuízos dos ajustes cardiovasculares, sugerindo cinética de oxigênio microvascular lenta durante exercício intenso. Objetivo: Testar hipótese que pacientes com DPOC apresentam não só menor performance muscular em exercício físico não dependente dos fatores centrais, mas também maior extração muscular de 02 independentemente da massa muscular. Métodos: Estudo transversal, 11 pacientes DPOC e 9 indivíduos saudáveis, gênero masculino, pareados pela idade. Avaliado espirometria, composição corporal, performance muscular por contração isométrica voluntária máxima (CIVM) em dinamometria isocinética e extração muscular de oxigênio pela técnica de NIRS. Teste $t$-Student e correlação de Pearson foram aplicados. Adotado $p<0,05$ como nível de significância. Resultados: Pacientes com DPOC moderado para grave (VEF1 = 44,5 \pm 9,6 \% predito; SpO2 $=94,6 \pm 1,6 \%$ ). Massa magra do membro inferior foi de 8,3 $\pm 0,9$ vs. 8,9 $\pm 1,0 \mathrm{Kg}(p=, 033)$, comparando DPOC e controle respectivamente. A redução saturação muscular de 02 corrigido pela massa muscular foi $53,2 \%$ maior $(p=0,044)$ no grupo DPOC na CIVM-1 e 149,6\% maior $(p=0,006)$ na CIVM-2. A taxa de extração microvascular de 02 corrigida pela massa muscular e trabalho total apresentou-se $114,5 \%$ maior $(p=0,043)$ no grupo DPOC na CIVM-1 e 210,5\% maior ( $p=0,015)$ na CIVM-2. Conclusão: Pacientes com DPOC apresentam baixa performance muscular e alta extração de 02 por unidade de massa muscular e por unidade de trabalho. A elevada extração de 02 sugere que mecanismos quantitativos e qualitativos podem ser determinantes da performance muscular em pacientes com DPOC.

Palavras-chave: Doença Pulmonar Obstrutiva Crônica. Contração Isométrica. Força Muscular. Consumo de Oxigênio. Metabolismo. Dinamômetro de Força Muscular. Eletromiografia.

\section{Introduction}

Changes in pulmonary function and imbalanced gas exchange during physical effort are characteristic of chronic obstructive pulmonary disease (COPD) $(1,2)$. Consequently, the interaction of aerobic exercise-COPD has been extensively studied. However, other factors reflect the complexity of COPD. Musculoskeletal dysfunction has been shown to be the major determinant of physical performance in this population. Anaerobic performance, instead of aerobic, is a better predictor of the ability to perform lower limb physical activity among patients with COPD (3). Several studies have demonstrated that maximum strength is associated with the level of daily physical activity (4), it is a better predictor of mortality (compared to age, body mass index (BMI) and FEV1 - forced expiratory volume in the first second) (5) and correlates with peak oxygen consumption (peak VO2) and the oxygen uptake efficiency slope (OUES) (6) in COPD. Specifically, maximum isometric strength is better associated with numerous types of functional testing rather than the $\mathrm{VO}_{2 \text { peak }}$ and Watts $_{\text {peak }}$ obtained from cardiopulmonary testing (7).

The maximum force obtained by maximum voluntary isometric contraction (MVIC) on a dynamometer is a method of high reliability and reproducibility (8). Although the MVIC is present in hundreds of studies, its use has been summarized merely for strength evaluation, torque in Newtonmeter $(\mathrm{Nm})$, and less frequently for the work in Joules (J), while the determining physiological mechanisms of muscle performance, on this type of assessment, have received little attention, especially in COPD. 
Muscle oxygenation, the recruitment of muscle fibers, and the efficiency of the ATP pathway resynthesis are determining the force applied during sustained muscle contraction. These determinants of muscle efficiency are importantly altered in COPD $(9,10)$. In particular, muscle oxygenation is dependent on the: capillary density of muscle fibers, muscular oxidative function, myoglobin concentration, and blood flow to the muscles. In addition, the supply of oxygen to the working muscles also has a close relationship with the types of muscular activity performed (11). According to this scenario, COPD patients cannot only have decreased muscle performance ( $\mathbf{N m}$, Joules) during physical exercise (MVIC) not dependent on central factors (cardiorespiratory), but also greater muscle $\mathrm{O}_{2}$ extraction $\left(\checkmark\right.$ muscle $\mathrm{O}_{2}$ saturation $\left(\mathrm{SmO}_{2} \%\right)$ and $\boldsymbol{\gamma}$ of microvascular $\mathrm{O}_{2}$ extraction rate $\left(\mathrm{E}_{\mu v a s c} \mathrm{O}_{2}, \%\right)$ regardless of muscle mass.

\section{Methods}

This study was approved by the Research Ethics Committee of the Federal University of São Paulo (CEP 1196/11). All participants were informed about the procedures and risks present and signed the Terms of Free and Informed Consent form.

The sample of this study consisted of 11 patients with COPD, male, referred by the pulmonology clinic of the Federal University of São Paulo (UNIFESP), aged over 60 years, and BMI less than $30 \mathrm{~kg} / \mathrm{cm}^{2}$, compared to nine healthy volunteers, paired by age and gender. The COPD group was determined according to the Global Initiative for Chronic Obstructive Lung Disease (GOLD) and classified as stage II-III; showing forced expiratory volume $\left(\mathrm{FEV}_{1}\right)$ less than $80 \%$ of predicted value and $\mathrm{FEV}_{1} /$ forced vital capacity (FVC) less than 0.70 .

All patients were stable in the previous four weeks. None of the participants were involved in a rehabilitation program, used corticosteroids, or oxygen therapy. Cardiac, renal, hematological, endocrine, hepatic, neurological, vascular or orthopedic disorders that prevented the study were considered as exclusion criteria.

\section{Spirometry}

The COPD group underwent spirometry analysis by the Clinical Pulmonary Function Spirometry-CPF-S ${ }^{\mathrm{TM}}$ system (Medical Graphics Corporation, St. Paul, MN, USA). The airflow was measured using a Pitot tube
(Prevent Pneumotach ${ }^{\mathrm{TM}}$ ); a flow and volume calibration was performed with all tests, considering the temperature, humidity and local barometric pressure. Fifteen minutes after administration of $400 \mu \mathrm{g}$ of Salbutamol, a repeated measurement was obtained, and the patients completed at least three forced expiratory maneuvers, which is acceptable and reproducible in accordance with the Guidelines for Lung Function of the Brazilian Society of Pneumonology and Thoracics (Sociedade Brasileira de Pneumologia e Tisiologia - SBPT).

\section{Body composition}

The assessment of body composition was performed by dual-energy X-ray absorptiometry (DEXA), using the DPX-IQ device (Lunar Radiation, Madison, WI). The source and detector were passed through the body, allowing for image reconstruction of tissues and quantification of total lean body mass in different segments. The presence of depletion was determined by the depletion index (12) (FFMI) $=(($ Fat Mass - Free Mass) $/$ height $^{2}$ ), being positive when $\leq 16 \mathrm{Kg} / \mathrm{m}^{2}$.

\section{Muscular oxygenation}

Muscle oxygenation was assessed by the near-infrared spectroscopy technique (NIRS), using the Oxiplex TS ${ }^{\mathrm{TM}}$ Model 99200 (Champaign, IL, USA) with a modulated frequency of $110 \mathrm{MHz}$. This technique allows fora non-invasive measurement of total hemoglobin and muscle saturation, among other variables, from the application of the Photon migration theory $(13,14)$. Both absorption and dispersion coefficients are determined from the changes in amplitude modulation, by the mean light intensity, and in the change phase. Thus, it measures the absolute level of absorption and scattering of light in tissues. Consequently, the variables mentioned can be obtained.

The muscular oxygenation profile was assessed in the medial vastus lateralis muscle portion; the probe was positioned around 10 to $12 \mathrm{~cm}$ above the patella and covered with a black band, to avoid loss of light and possible interference from external luminosity. The probe used had a 3.0 - $4.4 \mathrm{~cm}$ distance between the four light emitters and the detector. The penetration of the emitted light is $=2 \mathrm{~cm}$ from the surface of the skin (i.e., half the distance between the emitter and detector) (13), which proved to be sufficient for achieving a light signal reflected from the target muscle (15). The light absorption was measured in different spectra ( $690 \mathrm{~nm}$ to $830 \mathrm{~nm}$ ). At a wavelength 
of $830 \mathrm{~nm}$, both oxyhemoglobin as well as deoxyhemoglobin exhibited similar absorption coefficients. The light absorption at this wavelength is proportional to the total hemoglobin on the evaluated muscle. The NIRS technique does not allow a separate evaluation between hemoglobin and myoglobin, due to their similar characteristics. However, due to the relationship between the hemoglobin and myoglobin concentrations in human muscle, the signal obtained is considered as if it is derived only from hemoglobin (14). The absolute concentrations of total hemoglobin (HBT $(\mu \mathrm{M} / \mathrm{L})$ and muscular oxygen saturation $\left(\mathrm{SmO}_{2}(\%)\right)$ was obtained (16). The microvascular $\mathrm{O}_{2}$ extraction $\left(\mathrm{E}_{\mu \mathrm{vasc}} \mathrm{O}_{2}\right)$ was obtained using the following equation (17).

$$
\mathrm{E}_{\mathrm{v}} \mathrm{ascO}_{2}=\left[\frac{\mathrm{SpO}_{2}-\mathrm{SmO}_{2}}{\mathrm{SpO}_{2}}\right] * 100
$$

$\mathrm{SpO}_{2}$ is the saturation of oxygenated hemoglobin in arterial blood, measured by pulse oximetry in the right hand (POX 010-340; Mediaid, Torrance, CA). $\mathrm{SmO}_{2}$ is the oxygen saturation of hemoglobin in venous blood within the muscle, measured in the belly of the vastus lateralis muscle of the exercised limb.

For each of these variables, the mean of the three last seconds before the beginning of the MVIC and the mean of the final three seconds of the MVIC was calculated. Consequently, the amplitude variation derived from the difference between these means was obtained.

\section{Maximal voluntary isometric contraction}

Isokinetic dynamometry (Con-Trex ${ }^{\mathrm{TM}}, \mathrm{CH} 8046$ Zurich, Switzerland) was used for MVIC evaluation of the knee extensor muscle of the dominant limb (18). In a sitting position, with $100^{\circ}$ of knee flexion and the point of support at the distal portion of the leg, the subjects were tested twice on isometric force for 20 seconds with an interval of five minutes between tests. The maximum torque, high torque and total work were obtained.

\section{Statistical analysis}

Data normality was verified by the Shapiro-Wilk normality test. For the between-groups analysis, the independent Student t-test was used. The correlations were verified using the Pearson correlation test. The Statistical Process for the Social Sciences software, version 20.0 (SPSS ${ }^{\mathrm{TM}}$, Chicago, IL, USA), was used for statistical analysis. The type I error probability was established at 0.05 for all tests.

\section{Results}

Demographic data. No significant differences were identified between groups related to age and anthropometric data. Although differences in BMI were not observed, the muscle mass of the right lower limb of the COPD group was $9.8 \%(p=0.033)$ lower than the control group. The COPD group showed, as expected, low percentages of $\mathrm{FEV}_{1}$ and $\mathrm{FEV}_{1} / \mathrm{FVC}$ ratio compared to the predicted. A significantly lower $\mathrm{O}_{2}$ saturation pulse was identified in the COPD group than in the control group. The hemodynamic variables did not differ between groups, however, a trend was observed $(p=0.084)$ for increased resting heart rate in the COPD group (Table 1).

Table $\mathbf{l}$ - General characteristics of the COPD group and control group

\begin{tabular}{|c|c|c|c|}
\hline Variables & $\begin{array}{l}\text { COPD group } \\
\qquad(\mathrm{n}=11)\end{array}$ & $\begin{array}{l}\text { Control } \\
\text { group } \\
(\mathrm{n}=9)\end{array}$ & $\mathbf{P}$ \\
\hline Age (Years) & $63.7 \pm 5.5$ & $65.7 \pm 3.8$ & 0.363 \\
\hline Height (cm) & $166.3 \pm 5.5$ & $170.7 \pm 7.8$ & 0.158 \\
\hline Weight (Kg) & $70.51 \pm 10.7$ & $76.7 \pm 11.6$ & 0.231 \\
\hline BMI (Kg/m2) & $25.4 \pm 3.10$ & $26.2 \pm 3.33$ & 0,554 \\
\hline LMRLL (kg) & $8.3 \pm 0.9$ & $9.2 \pm 0.5$ & 0.033 \\
\hline $\begin{array}{l}\text { FEV1 (\% } \\
\text { predicted) }\end{array}$ & $44.5 \pm 9.6$ & - & - \\
\hline $\begin{array}{l}\text { FEV1/ FVC (\% } \\
\text { predicted) }\end{array}$ & $53.0 \pm 11.7$ & - & - \\
\hline Sp02rest (\%) & $94.6 \pm 1.6$ & $96.6 \pm 1.3$ & 0.008 \\
\hline HRrest (bpm) & $82 \pm 12$ & $73 \pm 7$ & 0.084 \\
\hline SBPrest (mmHg) & $122.7 \pm 9.0$ & $126.6 \pm 11.1$ & 0.395 \\
\hline DBPrest (mmHg) & $78.1 \pm 6.0$ & $77.7 \pm 6.6$ & 0.888 \\
\hline \multicolumn{4}{|c|}{$\begin{array}{l}\text { Note: Data presented as mean } \pm \text { standard deviation. } \mathrm{BMI}\left(\mathrm{kg} / \mathrm{m}_{2}\right) \text {, Body } \\
\text { mass index in kilograms per square meter; } \mathrm{FEV}_{1} \text {, forced expiratory volume } \\
\text { in first second; } \mathrm{LM}_{\mathrm{RL}} \text { lean mass in right lower limb ; } \mathrm{SpO}_{2} \text {, pulse oxygen } \\
\text { saturation; } \mathrm{HR} \text {, heart rate; } \mathrm{SBP} \text {, systolic blood pressure; } \mathrm{DBP} \text {, diastolic } \\
\text { blood pressure; rest, values obtained at rest. FVC, forced vital capacity. }\end{array}$} \\
\hline
\end{tabular}


Muscle performance. In all investigated muscular performance indices ( work $_{\text {total }}(\mathrm{J})$, torque $\mathrm{e}_{\text {peak }}(\mathrm{Nm})$ and

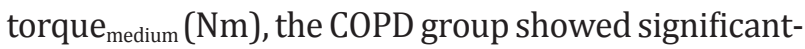
ly lower values, both in the first as well as in the second maximal voluntary isometric contraction (Table 2).

Table 2 - Maximum voluntary isometric contraction evaluation

\begin{tabular}{cccc}
\hline Variables & $\begin{array}{c}\text { COPD group } \\
(\mathrm{n}=11)\end{array}$ & $\begin{array}{c}\text { Control group } \\
(\mathrm{n}=9)\end{array}$ & $\mathrm{p}$ \\
\hline
\end{tabular}

$1^{\text {a MVIC }}$

$\begin{array}{lccc}\text { Work total }(\mathbf{J}) & 1863.4 \pm 589.5 & 2293.2 \pm 544.4 & 0.049 \\ \begin{array}{l}\text { Torquepeak (Nm) } \\ \begin{array}{l}\text { Torquemedium } \\ \text { (Nm) }\end{array}\end{array} & 116.1 \pm 31.3 & 148.9 \pm 18.6 & 0.013 \\ & 88.7 \pm 24.0 & 114.6 \pm 27.2 & 0.037\end{array}$

$2^{\mathrm{a}} \mathrm{MVIC}$

\begin{tabular}{lccc} 
Work total $(\mathrm{J})$ & $1777.1 \pm 403.5$ & $2193.9 \pm 555.8$ & 0.048 \\
$\begin{array}{l}\text { Torquepeak (Nm) } \\
\begin{array}{l}\text { Torquemedium } \\
\text { (Nm) }\end{array}\end{array}$ & $119.0 \pm 30.6$ & $145.2 \pm 25.1$ & 0.034 \\
\hline
\end{tabular}

Note: Data presented as mean \pm standard deviation. Maximal voluntary isometric contraction (MVIC); Newton-meters (Nm); Joules (J).

No significant differences were observed in muscle $\mathrm{O}_{2}$ saturation $\left(\mathrm{SmO}_{2} \%\right)$ and in microvascular $\mathrm{O}_{2}$ extraction rate $\left(\mathrm{E}_{\mu v a s c} \mathrm{O}_{2}, \%\right)$ at rest, when the groups were compared. However, significant differences were observed in the deltas of these variables. The reduction delta of the muscular $\mathrm{O}_{2}$ saturation, when corrected by the muscle mass of the lower limb, was $53.2 \%$ higher $(p=0.044)$ in the COPD group in MVIC-1 and 149.6\% higher $(\mathrm{p}=0.006)$ in MVIC-2 when compared to the control group (Figure 1). When the microvascular $\mathrm{O}_{2}$ extraction rate was corrected by the amount of muscle mass of the lower limb and also corrected by the total work done $(\% / \mathrm{kg} / \mathrm{J})$, it was $114.5 \%$ higher $(\mathrm{p}=0.043)$ in the COPD group with the MVIC-1 and $210.5 \%$ higher ( $p=0.015$ ) with the MVIC-2, when compared to the control group (Figure 2).

Significant correlations were observed between the muscle mass of the lower limb with the maximum torque in both groups. But this correlation was stronger in the COPD group (Figure 3).

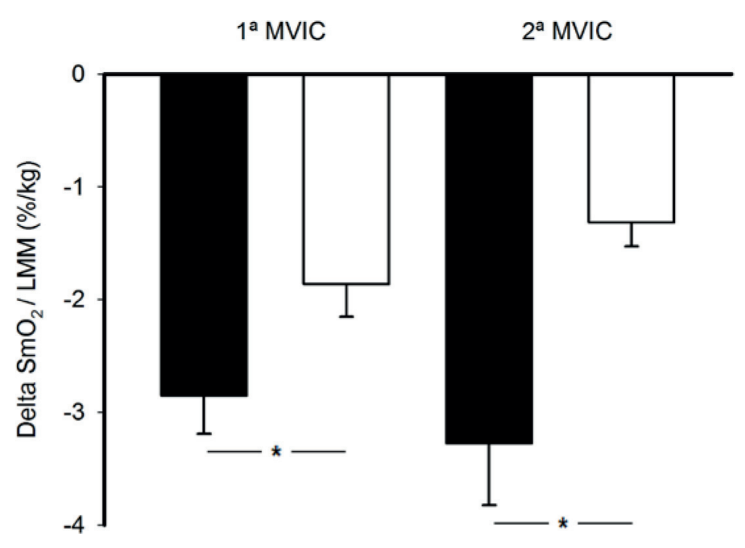

Figure 1 - Mean and Standard Deviation. 02 muscle saturation delta adjusted by the leg muscle mass. Note the worst adaptation to stress in the COPD group by reducing muscle saturation. * $\mathrm{P}<0.05$ on the analysis between groups.

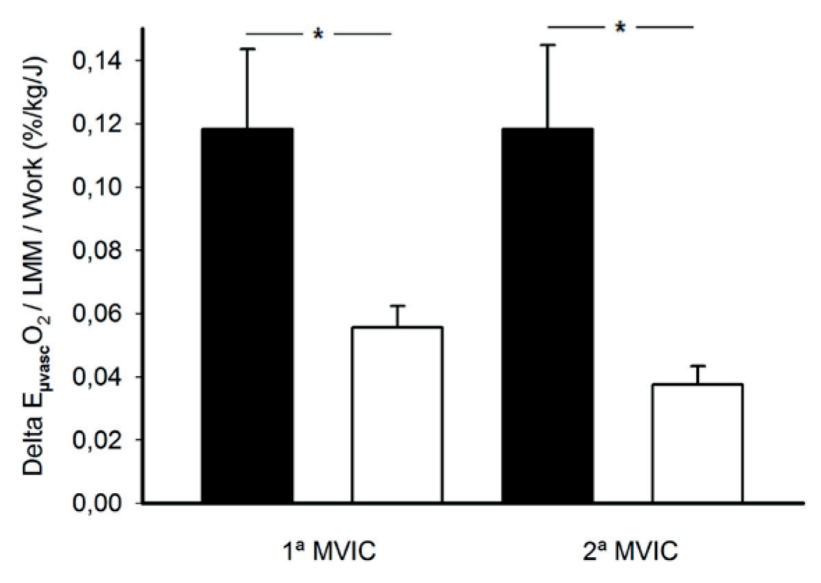

Figure 2 - Mean and standard deviation. Microvascular 02 extraction delta corrected by the leg muscle mass (LMM) and the total work in the MVIC. Note the high energy cost according to the work performed by COPD group by mean of high 02 extraction. $* \mathrm{P}<0.05$ on the analysis between groups.
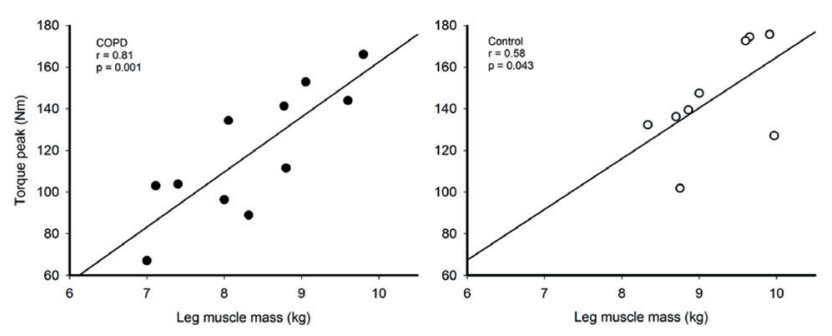

Figure 3 - Pearson's correlation. Nm - Newton meter. Note the significant influence of muscle mass in muscle strength, especially in the COPD group. 


\section{Discussion}

The main findings of this study were the high $\mathrm{O}_{2}$ extraction and reduced ability to generate work in the knee extensor muscles in patients with COPD. Consequently, a high $\mathrm{O}_{2}$ extraction per unit of work was observed.

\section{Low muscular capacity}

Several aspects of local and systemic character can justify the low muscle performance observed in different types of physical exercise performed by patients with COPD. However, the maximal voluntary isometric contraction was used in this study, and therefore, systemic factors had less importance in muscle performance. Studies have shown that blood flow is importantly reduced during MVIC (19) and thus, muscle performance is further dependent on the intracellular muscle status. We are aware that during the isometric contractions, blood flow can be significantly reduced by over $25 \%$ to $35 \%$ of MVIC intensities (19). The reduced oxidative capacity associated with reduced blood flow (?intramuscular pressure on isometrics) (19) imply a greater resynthesis of ATP by anaerobic pathways with increased lactate, $\mathrm{H}^{+}$and potassium imprisonment, with a consequent decline in contractile efficiency (20). This cascade of events, present in healthy individuals, is even more pronounced in COPD. The reduction in muscle oxidative enzymes (19), mitochondrial dysfunction (9), changes in the percentage distribution of type I and II fibers (10) and negative changes in energy metabolism, observed by spectroscopy of phosphorus ${ }^{31}$ by magnetic resonance (21), can justify this minor contractile efficiency observed in COPD (Table 2).

Patients with COPD exhibit loss of muscle mass from 18 to $36 \%$, and this loss is associated with increased morbidity and mortality (22 - 24). The reduced contractile efficiency could be justified by this lower lean mass, especially given the strong correlation observed in this study, (Fig 3) and the findings obtained in other studies conducted by this laboratory, in which strong correlations were observed between muscle mass of the lower limb with peak torque, isometric force and total work in patients with COPD (25, 26). However, this scenario was characterized by less muscle mass (agent) and lower torque or generated work (product), which does not explain the increased
$\mathrm{O}_{2}$ extraction observed in this study (consta 7 t of proportionalit: extracti $\mathrm{O}_{2} \propto$ agent $\Leftrightarrow$ product).

\section{The high $\mathrm{O}_{2}$ extraction in COPD}

Changes in diffusion and convective transport of $\mathrm{O}_{2}$ may explain the higher values of $\mathrm{O}_{2}$ extraction, as well as a greater fatigue in COPD, as demonstrated in detail by Katayama etal (27). However, patients were not hypoxic and did not show clinical signs of hypoxemia during the protocol, in this study. When comparing patients with COPD and healthy people, Chiappa et al., showed that at high intensities of exercise, the $\mathrm{O}_{2}$ consumption was significantly higher in COPD patients, suggesting a slower kinetics of $\mathrm{O}_{2}$ delivery during intense exercise microvascular (28). Although in the present study, a higher $\mathrm{O}_{2}$ extraction was observed, the same mechanistic behavior could not be anticipated by the characteristics of maximum voluntary contraction ( 1 intramuscular pressure $=\boldsymbol{V}$ of blood flow) .

Many mechanisms interact synergistically to maintain physical effort (29), however MVIC requires a high ATP demand and therefore a significant activation of the anaerobic resynthesis process (phosphocreatine and glycolysis), leading to accumulation of metabolites (e.g., lactate, inorganic phosphate ions, hydrogen) and reduced contractile efficiency (30). However, concomitant activation of type I and type II muscle fibers in a MVIC results in a significant participation of oxidative phosphorylation in this exercise modality (31), and may contribute more significantly $(\Delta 16 \%)$ with the maintenance of contractile efficiency, than the phosphocreatine $(\% \Delta 9)$ and anaerobic glycolysis $(\Delta 10 \%)$ in the resynthesis of ATP (32). Specifically in COPD, the reduction in the ratio of type I/type II muscle fibers (33) can significantly change the $\mathrm{O}_{2}$ extraction.

Several studies have shown that the energy cost per unit of work generated is higher in type II fibers (34). A greater extraction of $\mathrm{O}_{2}$ has been observed in the gastrocnemius muscle (type II fibers) compared to the soleus muscle (type I fibers) during muscle contractions induced by electrical stimulation (35). This behavior is mainly due to the metabolic characteristics of these fibers. The oxidative phosphorylation rate is controlled by the concentration of adenosine diphosphate (ADP), and high concentrations of ADP can be observed in patients with COPD in routine activities such as walking (36). Moreover, mitochondrial $\mathrm{O}_{2}$ consumption rate is closely correlated to the muscle 
phosphocreatine break-down (37), which is greater per unit time in type II fibers (38). It can be assumed that the vascular changes in the musculature of the COPD patients ( $\%$ type II fibers) associated with the characteristics of muscle recruitment the MVIC, would be responsible for the high consumption of $\mathrm{O}_{2}$, leading to a reduction in muscle $\mathrm{O}_{2}$ pressure $\left(\mathrm{PO}_{2}\right.$, $\mathrm{mmHg}$ ), and consequently, to a greater pressure gradient of $\mathrm{O}_{2}$ extraction in thepulation.

\section{Clinical applications}

The gaining of strength and muscular hypertrophy are closely linked to the intensity of exercise or the percentages of load used. Several studies have shown that working intensities below $30 \%$ of one maximal repetition are unable to promote significant adjustments (39). The improvement in muscle strength not only affects the improvement of activities of daily living, but also contributes to the reduction of mortality. Thus, understanding the mechanisms involved in muscle performance in high intensity activities is critical to the adequacy of rehabilitation programs.

\section{Conclusion}

In summary, this study confirms the hypothesis that muscle performance is decreased in COPD and, although the maximum force (torque) is dependent on muscle mass, this study provides further support to the concept that less muscular efficiency (work) in COPD is not totally dependent on the amount of muscle mass. The high microvascular $\mathrm{O}_{2}$ extraction observed suggests that not only quantitative mechanisms, but also qualitative, may be determinants of muscle performance in patients with chronic obstructive pulmonary disease.

\section{References}

1. Aliverti A, Macklem PT. How and why exercise is impaired in COPD. Respiration. 2001;68(3):229-39.

2. Soriano JB, Rodriguez-Roisin R. Chronic obstructive pulmonary disease overview: epidemiology, risk factors, and clinical presentation. Proc Am Thorac Soc. 2011;8(4):363-7.
3. Chura RL, Marciniuk DD, Clemens R, Butcher SJ. TestRetest Reliability and Physiological Responses Associated with the Steep Ramp Anaerobic Test in Patients with COPD. Pulm Med. 2012;2012:653831.

4. Osthoff AK, Taeymans J, Kool J, Marcar V, van Gestel AJ. Association between peripheral muscle strength and daily physical activity in patients with COPD: a systematic literature review and meta-analysis. J Cardiopulm Rehabil Prev. 2013;33(6):351-9.

5. Swallow EB, Reyes D, Hopkinson NS, Man WD, Porcher $\mathrm{R}$, Cetti EJ, et al. Quadriceps strength predicts mortality in patients with moderate to severe chronic obstructive pulmonary disease. Thorax. 2007;62(2):115-20.

6. Müller P, Viegas C, Patusco L. Muscle strength as a determinant of oxygen uptake efficiency and maximal metabolic response in patients with mild-to-moderate COPD. J Bras Pneumol. 2012;38(5):541-9.

7. Butcher SJ, Pikaluk BJ, Chura RL, Walkner MJ, Farthing JP, Marciniuk DD. Associations between isokinetic muscle strength, high-level functional performance, and physiological parameters in patients with chronic obstructive pulmonary disease. Int J Chron Obstruct Pulmon Dis. 2012;7:537-42.

8. Robles PG, Mathur S, Janaudis-Fereira T, Dolmage TE, Goldstein RS, Brooks D. Measurement of peripheral muscle strength in individuals with chronic obstructive pulmonary disease: a systematic review. J Cardiopulm Rehabil Prev. 2011;31(1):11-24.

9. Gosker HR, Wouters EF, van der Vusse GJ, Schols AM. Skeletal muscle dysfunction in chronic obstructive pulmonary disease and chronic heart failure: underlying mechanisms and therapy perspectives. Am J Clin Nutr. 2000;71(5):1033-47.

10. Gosker HR, van Mameren H, van Dijk PJ, Engelen MP, van der Vusse GJ, Wouters EF, et al. Skeletal muscle fibre-type shifting and metabolic profile in patients with chronic obstructive pulmonary disease. Eur Respir J. 2002;19(4):617-25.

11. Demura S, Nakada M, Yamaji S, Nagasawa Y. Relationships between force-time parameters and muscle oxygenation kinetics during maximal sustained isometric grip and maximal repeated rhythmic grip with different contraction frequencies. J Physiol Anthropol. 2008;27(3):161-8. 
12. Vermeeren MA, Creutzberg EC, Schols AM, Postma DS, Pieters WR, Roldaan AC, et al. Prevalence of nutritional depletion in a large out-patient population of patients with COPD. Respir Med. 2006;100(8):1349-55.

13. Chance B, Nioka S, Kent J, McCully K, Fountain M, Greenfeld R, et al. Time-resolved spectroscopy of hemoglobin and myoglobin in resting and ischemic muscle. Anal Biochem. 1988;174(2):698-707.

14. Quaresima V, Lepanto R, Ferrari M. The use of near infrared spectroscopy in sports medicine. J Sports Med Phys Fitness. 2003;43(1):1-13.

15. McCully KK, Hamaoka T. Near-infrared spectroscopy: what can it tell us about oxygen saturation in skeletal muscle? Exerc Sport Sci Rev. 2000;28(3):123-7.

16. van Beekvelt MC, Colier WN, Wevers RA, van Engelen BG. Performance of near-infrared spectroscopy in measuring local O(2) consumption and blood flow in skeletal muscle. J Appl Physiol (1985). 2001;90(2):511-9.

17. Kissack CM, Weindling AM. Peripheral blood flow and oxygen extraction in the sick, newborn very low birth weight infant shortly after birth. Pediatr Res. 2009;65(4):462-7.

18. Maffiuletti NA, Bizzini M, Desbrosses K, Babault N, Munzinger U. Reliability of knee extension and flexion measurements using the Con-Trex isokinetic dynamometer. Clin Physiol Funct Imaging. 2007;27(6):346-53.

19. de Ruiter CJ, Goudsmit JF, van Tricht JA, de Haan A. The isometric torque at which knee-extensor muscle reoxygenation stops. Med Sci Sports Exerc. 2007;39(3):443-53.

20. Miller RG, Boska MD, Moussavi RS, Carson PJ, Weiner MW. 31P nuclear magnetic resonance studies of high energy phosphates and $\mathrm{pH}$ in human muscle fatigue. Comparison of aerobic and anaerobic exercise. J Clin Invest. 1988;81(4):1190-6.

21. Wuyam B, Payen JF, Levy P, Bensaidane H, Reutenauer $\mathrm{H}$, Le Bas JF, et al. Metabolism and aerobic capacity of skeletal muscle in chronic respiratory failure related to chronic obstructive pulmonary disease. Eur Respir J. 1992;5(2):157-62.

22. Schols AM, Soeters PB, Dingemans AM, Mostert R, Frantzen PJ, Wouters EF. Prevalence and characteristics of nutritional depletion in patients with stable COPD eligible for pulmonary rehabilitation. Am Rev Respir Dis. 1993;147(5):1151-6.
23. Rabinovich RA, Vilaro J. Structural and functional changes of peripheral muscles in chronic obstructive pulmonary disease patients. Curr Opin Pulm Med. 2010;16(2):123-33.

24. Schols AM. Nutrition in chronic obstructive pulmonary disease. Curr Opin Pulm Med. 2000;6(2):110-5.

25. Malaguti C, Napolis LM, Villaca D, Neder JA, Nery LE, Dal Corso S. Relationship between peripheral muscle structure and function in patients with chronic obstructive pulmonary disease with different nutritional status. J Strength Cond Res. 2011;25(7):1795-803.

26. Malaguti C, Nery LE, Dal Corso S, Napolis L, De Fuccio $\mathrm{MB}$, Castro $\mathrm{M}$, et al. Scaling skeletal muscle function to mass in patients with moderate-to-severe COPD. Eur J Appl Physiol. 2006;98(5):482-8.

27. Katayama K, Amann M, Pegelow DF, Jacques AJ, Dempsey JA. Effect of arterial oxygenation on quadriceps fatigability during isolated muscle exercise. Am J Physiol Regul Integr Comp Physiol. 2007;292(3):R1279-86.

28. Chiappa GR, Borghi-Silva A, Ferreira LF, Carrascosa C, Oliveira CC, Maia J, et al. Kinetics of muscle deoxygenation are accelerated at the onset of heavyintensity exercise in patients with COPD: relationship to central cardiovascular dynamics. J Appl Physiol. 2008;104(5):1341-50.

29. Taylor JL, Gandevia SC. A comparison of central aspects of fatigue in submaximal and maximal voluntary contractions. J Appl Physiol (1985). 2008;104(2):542-50.

30. Cairns SP, Lindinger MI. Do multiple ionic interactions contribute to skeletal muscle fatigue? J Physiol. 2008;586(17):4039-54.

31. Beltman JG, Sargeant AJ, van Mechelen W, de Haan A. Voluntary activation level and muscle fiber recruitment of human quadriceps during lengthening contractions. J Appl Physiol (1985). 2004;97(2):619-26.

32. Sirikul B, Hunter GR, Larson-Meyer DE, Desmond R, Newcomer BR. Relationship between metabolic function and skeletal muscle fatigue during a 90 s maximal isometric contraction. Appl Physiol Nutr Metab. 2007;32(3):394-9.

33. Rabinovich RA, Vilaro J. Structural and functional changes of peripheral muscles in chronic obstructive pulmonary disease patients. Curr Opin Pulm Med. 2010;16(2):123-33. 
34. Rossiter HB, Ward SA, Howe FA, Kowalchuk JM, Griffiths JR, Whipp BJ. Dynamics of intramuscular 31P-MRS $\mathrm{P}(\mathrm{i})$ peak splitting and the slow components of $\mathrm{PCr}$ and 02 uptake during exercise. J Appl Physiol (1985). 2002;93(6):2059-69.

35. McDonough P, Behnke BJ, Padilla DJ, Musch TI, Poole DC. Control of microvascular oxygen pressures in rat muscles comprised of different fibre types. J Physiol. 2005;563(Pt 3):903-13.

36. Calvert LD, Steiner MC, Morgan MD, Singh SJ. Plasma ammonia response to incremental cycling and walking tests in COPD. Respir Med. 2010;104(5):675-81.

37. Cieslar JH, Dobson GP. Free [ADP] and aerobic muscle work follow at least second order kinetics in rat gastrocnemius in vivo. J Biol Chem. 2000;275(9):6129-34.

38. Karatzaferi C, de Haan A, Ferguson RA, van Mechelen W, Sargeant AJ. Phosphocreatine and ATP content in human single muscle fibres before and after maximum dynamic exercise. Pflugers Arch. 2001;442(3):467-74.

39. Fry AC. The role of resistance exercise intensity on muscle fibre adaptations. Sports Med. 2004;34(10):663-79.

Received in 05/29/2014

Recebido em 29/05/2014

Approved in 12/04/2015

Aprovado em 04/12/2015 
